\title{
Superficial Magnetic Characterization of the Araguainha Impact Structure
}

\author{
Henrique Moreira Santana*, Emilson Pereira Leite.
}

\begin{abstract}
The Araguainha Dome, located on the border between the states of GO and MT, in the Midwest of Brazil, is the largest impact crater in Latin America (diameter $\approx 40 \mathrm{~km}$ ). Geophysics has important tools for the characterization of this type of structure, and one of these tools is the analysis and interpretation of magnetic susceptibility (MS). This research proposes an MS analysis integrated with other geological and geophysical data. The result of this work is a magnetic map which contribute to the recognition of the impact structure showing the annular distribution of MS values with higher values around the central uplift.
\end{abstract}

\section{Key words:}

Magnetic Susceptibility, Araguainha Dome, Impact Crater.

\section{Introduction}

With a diameter of about $40 \mathrm{~km}$, Araguainha is the largest impact structure among the 11 existing craters in South America. This structure is of the complex type, formed by sediments of the Paraná Basin. It is located on the border between Goiás and Mato Grosso, centered at $16^{\circ} 47^{\prime} \mathrm{S}$ and $52^{\circ}-59^{\prime} \mathrm{W}$. The interior of the structure exposes a central uplift surrounded by an annular basin $5 \mathrm{~km}$ wide and two main rings 10-12 and 14-18 km from the center. Typical impact features, such as shatter cones, impact breccias and planar deformation features (PDFs) were found in the structure area, evidencing intense deformation and fusion [1].

The geophysical methods aid in the identification and detailing of surface and subsurface changes caused by meteorite impacts, allowing the characterization of partially or totally eroded and altered impact structures [2]. This way, the characterization by magnetic susceptibility (MS) measurements on the surface contributes to a more complete understanding of the structures and helps in the formulation of subsurface models. Thus, this project aims to complement the geophysical characterization of this important impact crater.

\section{Results and Discussion}

The data provided consist of MS values measured at 890 points along a structure with a portable magnetic susceptibility meter model KT-10 produced by Terraplus (Canada). Values range from 0.000667 to 58.366667 (x10 ${ }^{3} \mathrm{SI}$ ), with about $59 \%$ of the data between 0.027130 and $0.152900\left(\times 10^{-3} \mathrm{SI}\right)$. Chart 1 shows the main parameters obtained from MS.

Chart 1. Data of magnetic susceptibility (MS) $\left(\times 10^{-3} \mathrm{SI}\right)$ of Araguainha Dome.

\begin{tabular}{|c|c|c|c|c|}
\hline Unity & Points & $\begin{array}{c}\text { MS } \\
(\mathbf{m i n})\end{array}$ & $\begin{array}{c}\text { MS } \\
(\mathbf{m a x})\end{array}$ & $\begin{array}{c}\text { MS } \\
(\text { mean })\end{array}$ \\
\hline Furnas & 90 & 0.0037 & 0.9200 & 0.1296 \\
\hline Pta. Grossa & 124 & 0.0150 & 58.3667 & 5.3833 \\
\hline Aquidauana & 480 & 0.0007 & 7.4100 & 0.2490 \\
\hline Passa Dois & 98 & 0.0330 & 14.2667 & 0.6402 \\
\hline PM Granite & 17 & 0.0500 & 0.4000 & 0.1482 \\
\hline WS Granite & 53 & 0.0400 & 1.4000 & 0.2101 \\
\hline Pol. Breccia & 17 & 0.0300 & 1.8000 & 0.4999 \\
\hline
\end{tabular}

The interpolation of the data was done using the method of Ordinary Kriging in Oasis Montaj (Canada) software. Two different cell sizes, $2500 \mathrm{~m}$ (Figure 1) and $100 \mathrm{~m}$, were used. Higher values of MS are observed in the region around the central uplift, in the Ponta Grossa formation.
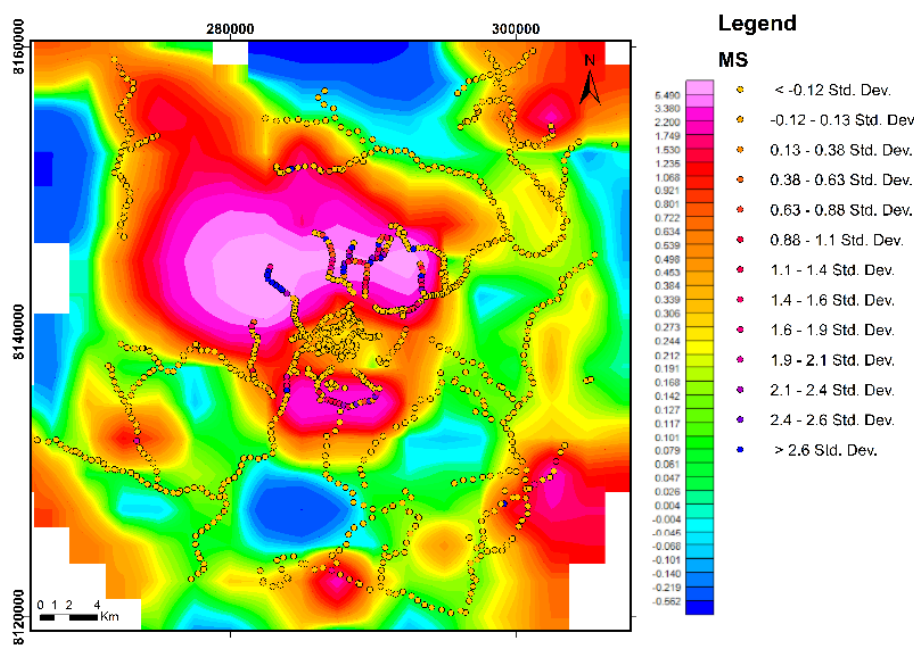

Image 1. Magnetic susceptibility of the Araguainha Dome $\left(\times 10^{-3} \mathrm{SI}\right)$.

\section{Conclusions}

The results obtained with the magnetic map allow: the identification of regions with higher magnetism, the association of these regions with the types of rock and shows the morphology and annular arrangement in which the geological units occur in the region. Thus, it is possible to attest to the importance of magnetic data in the characterization of impact structures.

\section{Acknowledgement}

The authors are grateful to FAPESP for research funding (2016/16021-5). To CNPq for the provision of the IC financial support. To Geologist Johann Lambert Silva for the provision of geophysical data.

[1] CRÓSTA, A.P. Mapeamento Geológico do Domo de Araguainha utilizando técnicas de Sensoriamento Remoto. 1982. 108p. Dissertação (Mestrado) - INPECNPq, São José dos Campos, São Paulo, 1982.p102.

[2] PILKINGTON, M.; GRIEVE, R. A. F. The geophysical signature of terrestrial impact craters. Reviews of Geophysics, v. 30, n. 2, p. 161-181, 1992. 